\title{
The association between serotonin-related gene polymorphisms and susceptibility and early sertraline response in patients with panic disorder
}

Zhili Zou, Yulan Huang, Jinyu Wang, Wenjiao Min and Bo Zhou* (D)

\begin{abstract}
Background: A number of studies have shown that genetic factor plays an important role in etiology of panic disorder (PD). The aim of the present study was to examine the association of serotonin-related gene polymorphisms with PD risk. Then, we analyzed the correlation between these gene polymorphisms and response to sertraline drug.

Methods: Two hundred thirty-three patients with PD and 231 healthy controls were enrolled in the study. Panic Disorder Severity Scale (PDSS) were administered to all subjects, and all patients in the study were also assessed after 4 weeks of treatment. The SLC6A4(rs140701, rs3813034, 5-HTTLPR and STin2), 5-HTR1A rs6295, 5-HTR2A rs6313 and COMT rs4680 gene polymorphisms were genotyped and assessed for the potential association.

Results: The allelic model showed that the SLC6A4 rs140701 polymorphism variant was significantly associated with increased risk of $\mathrm{PD}(\mathrm{OR}=0.624,95 \% \mathrm{Cl} 0.450-0.864, p<0.05)$, and a significant result was found in the dominant model $(\mathrm{OR}=0.546 ; 95 \% \mathrm{Cl}, 0.371-0.804, p<0.05)$. There was a significant difference in allele and genotype frequency between responders and nonresponders in the 5 -HTTLPR polymorphism $(\mathrm{OR}=0.205,95 \% \mathrm{Cl}$ $0.128-0.328 ; \mathrm{OR}=0.249,95 \% \mathrm{Cl} 0.155-0.401$, both $p<0.001$ ), indicating the PD patients with S-allele had a poorer response to sertraline than L-allele carriers.
\end{abstract}

Conclusions: The present study suggests that the SLC6A4 rs140701 polymorphism variant may be associated with susceptibility to PD, and 5-HTTLPR polymorphism may be a predictor of response to sertraline in the treatment of PD.

Keywords: Panic disorder, Serotonin transporter, Polymorphism, Setraline

\footnotetext{
* Correspondence: 252005884@qq.com

Psychosomatic Department, Sichuan Academy of Medical Science \& Sichuan Provincial People's Hospital, No. 32 West Second Section First Ring Road,

Chengdu, Sichuan 610072, P.R. China
}

(c) The Author(s). 2020 Open Access This article is licensed under a Creative Commons Attribution 4.0 International License, which permits use, sharing, adaptation, distribution and reproduction in any medium or format, as long as you give appropriate credit to the original author(s) and the source, provide a link to the Creative Commons licence, and indicate if changes were made. The images or other third party material in this article are included in the article's Creative Commons licence, unless indicated otherwise in a credit line to the material. If material is not included in the article's Creative Commons licence and your intended use is not permitted by statutory regulation or exceeds the permitted use, you will need to obtain permission directly from the copyright holder. To view a copy of this licence, visit http://creativecommons.org/licenses/by/4.0/ The Creative Commons Public Domain Dedication waiver (http://creativecommons.org/publicdomain/zero/1.0/) applies to the data made available in this article, unless otherwise stated in a credit line to the data. 


\section{Background}

Panic disorder is a common anxiety disorder characterized by sudden and unexpected panic attacks and accompany with obviously anticipatory anxiety. The estimated lifetime prevalence of PD is 3.4 to $4.7 \%[1,2]$. It typically occurs in young adults, and women are more likely to be affected than men [3]. However, the etiology of PD is complex and unclear. A meta-analysis showed genetic factors explain approximately $43 \%$ of the variance in the PD [4], indicating an important role in the pathological PD. Previous studies have consistently demonstrated serotonin involvement in the neurobiology of PD $[5,6]$. Clinical studies also demonstrated that selective serotonin-reuptake inhibitors (SSRIs) increasing the synaptic availability of $5-\mathrm{HT}$ and are effective in the treatment of PD [7]. Therefore, the certain variants in the serotonin-related genes, such as serotonin transporter (5-HTT), 5-HT1A receptor (5-HTR1A), 5-HT2A receptor (5HTR2A) and catechol-O-methyltransferase (COMT) genes, may influence 5-HT neurotransmission, and they are good candidates for the study of PD. A few studies have investigated the association between the 5HTT linked polymorphic region (5-HTTLPR), 5-HTR1A rs6295, 5-HTR2A rs6313, COMT rs4680 polymorphisms and PD [8-16]. However, the results were hardly replicable and the pathogenesis of PD remains to be clarified. It is important to note that previous studies have been conducted in different ethnic groups, few of them have examined the relationship between these gene polymorphisms and PD in Chinese population.

SSRIs are recommended as the first-line antidepressants in treatment for PD. However, not all patients can gain full response from these antidepressants. With the advancement of pharmacogenomic technologies, genetic variation has been identified to contribute to individual response to antidepressants. Pharmacogenomic studies focusing on candidate gene polymorphisms implicated in antidepressant response, especially in the serotonergic pathway. Abundant evidence has shown that serotoninrelated gene polymorphisms played an important role in the clinical effects of antidepressants. For example, a few studies investigated that 5-HTTLPR, intron 2 (STin2), 5HTR1A rs6295, 5-HTR2A rs6313 and COMT rs4680 polymorphisms associated with antidepressant response [17-26]. However, these findings are inconsistent and do not completely explain the predictive effects of antidepressants. To our knowledge, many previous studies have been conducted in other psychiatric disorders, such as major depressive disorder(MDD) [27-30], and few of them have conducted in PD. In addition, the different results of these studies might also be partly attributable to the differences in the type of antidepressant drug [31, 32]. Sertraline, a SSRI which has been used widely to treat PD for its prominent therapeutical effects and low incidence of adverse events [33], was the first-line treatment for PD. Hence, the first aim of this study was to investigate the association of serotonin-related gene polymorphisms including SLC6A4 (rs140701, rs3813034, 5-HTTLPR and STin2), 5-HTR1A rs6295, 5-HTR2A rs6313 and COMT rs4680 with PD risk, and the second aim was to examine the association between these single nucleotide polymorphisms (SNPs) and early response to sertraline treatment in PD.

\section{Methods \\ Participants}

Two hundred thirty-three patients with PD were recruited from inpatient and outpatient populations in the Department of Psychosomatic, Sichuan Provincial People's Hospital between May 2015 and December 2018(recruitment flow chart in Fig. S1). Diagnosis of PD was conducted according to the Structured Clinical Interview for the Diagnostic and Statistical Manual of Mental Disorders fourth edition (DSM-IV) (SCID-1) [34], which was administered by trained clinical psychiatrists. Patients with neurological diseases, and/or past or current episodes of MDD, generalized anxiety disorder(GAD), manic disorder, bipolar disorder, schizophrenia or any other psychiatric disorders were excluded. In addition, 231 healthy controls were recruited from the Center of Health Examination, Sichuan Provincial People's Hospital. The SCID-1 was also performed to exclude a lifetime or current diagnosis of PD, MDD, GAD, among others.

All subjects in this study were Han Chinese, and all subjects were free of acute or chronic somatic disorders. All patients were free of antidepressants or other psychotropic medications intake within 2 weeks before their examination. Demographic data and clinical presentations were obtained from medical records or qualified interviews. A 3-mL EDTA-anticoagulated peripheral blood sample was collected from every individual.

\section{Measures \\ Panic disorder severity scale(PDSS)}

The Panic Disorder Severity Scale is a valid and reliable inventory. Seven items are included in this scale, and each item is scored $0-4$ on a Likert scale ranging from "none" to "extremely severe" [35]. Also, the scale was translated into Chinese, and the PDSS-Chinese Version(PDSS-CV) has good internal consistency (Cronbach's alpha) with the overall score (0.83) [36].

\section{Treatment}

Setraline (100-200 mg qd) was administered to all patients for 4-week period. Other psychotropic medications were not permitted during the study except for benzodiazepine, which was prescribed occasionally for insomnia with a minimal dosage at bedtime. PDSS was assessed to all patients at baseline and after 4 weeks of 
treatment. Response was defined as a $40 \%$ or greater reduction in scores on the pre-treatment PDSS [37].

\section{SNP selection and genotyping}

The SNP selected was based on literature search and minor allele frequency(MAF) $>0.05$ of east Asian population from public databases. The references were listed in the Table S1. SNP genotyping was performed using an improved multiplex ligation detection reaction (iMLDR) technique which developed by Genesky Biotechnologies Inc. (Shanghai, China). The primer information of the reaction mixtures is described in Tables S2 and S3. The $20 \mu \mathrm{l}$ multiplex polymerase chain reaction (PCR) included 1 x GC-I buffer (Takara), $0.3 \mathrm{mM}$ dNTP, $3.0 \mathrm{mM} \mathrm{Mg}^{2+}, 1$ U HotStar Taq Polymerase (Qiagen Inc), $1 \mu$ genomic DNA(5-10 ng/ $\mu \mathrm{l})$, and $1 \mu \mathrm{l}$ Multiplex-PCR primermix. In addition, The 5-HTT of PCR reaction volume $(10 \mu \mathrm{l})$ included $10 \mathrm{x}$ buffer I (Qiagen Inc), Q Solution(Qiagen Inc.), $0.2 \mathrm{mM} \mathrm{Mg} \mathrm{2+,} 1 \mathrm{U}$ HotStarTaq polymerase (Qiagen Inc.), $1 \mu \mathrm{l}$ genomic DNA, and $1 \mu \mathrm{l}$ PCR primermix. The PCR cycling program was as follows: denaturation at $95^{\circ} \mathrm{C}$ for $2 \mathrm{~min}$, followed by 11 cycles of $94^{\circ} \mathrm{C}$ for 20s, annealing at $65^{\circ} \mathrm{C}$ for $40 \mathrm{~s}$ and $72{ }^{\circ} \mathrm{C}$ for $1.5 \mathrm{~min}$, and each cycle decreased $0.5^{\circ} \mathrm{C}$. The third step was set as 24 cycles of $94^{\circ} \mathrm{C}$ for $20 \mathrm{~s}, 59^{\circ} \mathrm{C}$ for $30 \mathrm{~s}$, finally, $72{ }^{\circ} \mathrm{C}$ for $2 \mathrm{~min}$ and $4{ }^{\circ} \mathrm{C}$ for hold. In addition, the 5-HTT of cycling program for PCR was $95^{\circ} \mathrm{C}$ for $2 \mathrm{~min}, 35$ cycles of amplification consisted of $94^{\circ} \mathrm{C}$ for $20 \mathrm{~s}$ and $72^{\circ} \mathrm{C}$ for $1.5 \mathrm{~min}$, and final extension at $68^{\circ} \mathrm{C}$ for $60 \mathrm{~min}$ and a hold at $4^{\circ} \mathrm{C} .5 \mathrm{U}$ SAP and 2 Exonucleaselwere used to purify the PCR product at $37^{\circ} \mathrm{C}$ and then $15 \mathrm{~min}$ of $75^{\circ} \mathrm{C}$ for inactivation. $2 \mu \mathrm{l}$ purified multi-

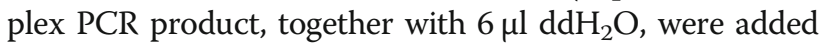
into the ligation reaction containing $1 \mu \mathrm{l}$ of $10 \times$ ligation buffer, $0.25 \mu \mathrm{l}$ Tag DNA ligase, 5' ligationprimer $(1 \mu \mathrm{M})$ $0.4 \mu \mathrm{l}, 3^{\prime}$ ligationprimer $(2 \mu \mathrm{M}) 0.4 \mu \mathrm{l}$. The ligation cycling program was set as 38 cycles $\times\left(94{ }^{\circ} \mathrm{C}\right.$ for $1.5 \mathrm{~min}$ and $56^{\circ} \mathrm{C}$ for $4 \mathrm{~min}$ ), and a hold at $4^{\circ} \mathrm{C}$. After PCR, $0.5 \mu$ ligation product was taken for Sequencing with $0.5 \mu \mathrm{L}$ Liz500 Size Standard, and $9 \mu \mathrm{HiDi}$ mixture (ABI3730XL). The raw data were analyzed by Gene Mapper v4.1 software (AppliedBiosystems, USA). All primers, probes and labeling oligos were designed by and ordered from Genesky Biotechnologies Inc.

\section{Statistical analysis}

The data were analyzed using SPSS version 18.0 software (SPSS Inc., Chicago, IL, USA). Student's $t$-tests were used for inter group comparisons of continuous variables, with Pearson's chi-square tests utilized for categorical variables. $P$ values for the Hardy-Weinberg equilibrium (HWE) were tested by Pearson's chi-square test, and $P>0.05$ indicated no significant deviation in allele and genotype frequencies among subjects. Associations between SNPs and disease status were determined based on the distributions of allelic frequencies and genetic models (additive, dominant, and recessive model), and odds ratios $(O R s)$ and 95\% confidence intervals $(\mathrm{CIs})$ were performed in unconditional logistic regression analysis using PLINK v1.07, 20 adjusting for age, gender, educational level and resident location. To protect from Type I error, a Bonferroni correction was conducted. For all analyses, statistical tests were two-tailed and an alpha level of 0.05 was used to define statistical significance. Power calculation $(\alpha=0.05)$ was performed using Power and Sample Size Calculation Software (3.6.1).

\section{Results}

\section{Demographic data and clinical manifestations}

A total of 233 patients with PD (92 men, 141 women) and 231 controls (98 men, 133 women) were selected. The average age of the study sample was $(35.65 \pm 9.77)$ years, and the mean age of the control group was $(36.96 \pm 7.82)$ years. $53.6 \%$ of the patients $(n=125)$ were residing in urban locations, and $46.4 \%$ of the patients $(n=108)$ were residing in rural locations. No statistically significant differences were noted between cases and controls in terms of sex, age, education level and resident location $(p>0.05)$. In addition, the mean total duration of panic disorder was $(2.49 \pm 1.45)$ years. The PDSS score was $15.47 \pm 3.82$ before medication and $9.51 \pm 3.81$ after 4 weeks of medication, and the score was significantly reduced after medication $(p<0.05)$. According to the definition of remission, the response rate was $42.1 \%(n=98)$. The demographic details of the sample are given in Table 1.

\section{Association of serotonin-related gene polymorphisms with PD risk}

To determine whether the sample size of this study has power to detect the real difference, a power analysis was performed. From the result of Table S4, the sample size of 233 vs 231 ensured that a two-sided test with $\alpha=0.05$ had $80 \%$ power to detect an relative risk of $2.0(\Psi=2.0)$. All selected SNPs fulfilled the HWE in both cases and controls $(p>0.05)$. To determine the extent of linkage disequilibrium (LD) between the two polymorphisms (rs140701, rs3813034) in SLC6A4 gene, standardized LD coefficient D' was calculated for this pair of polymorphisms. The $\mathrm{R}^{2}$ and $\mathrm{D}^{\prime}$ was 0.510 and 0.717 respectively, indicating weak LD between these two polymorphisms.

The allele distributions of SLC6A4 (rs140701 and rs3813034) were significantly different between PD cases and the controls $(\mathrm{OR}=0.624,95 \%$ CI $0.450-0.864, p=$ 0.004 ; $\mathrm{OR}=0.705,95 \%$ CI $0.509-0.975, p=0.034$; respectively). However, only SLC6A4 rs140701 remained significant after adjusting for Bonferroni's multiple test$\operatorname{ing}(p=0.028)$. After adjustment for age, gender, educational level and resident location, the dominant model of 
Table 1 Demographic and clinical characteristics in patients with PD and controls

\begin{tabular}{|c|c|c|c|c|}
\hline Variable & $\mathrm{PD}(n=233)$ & Controls $(n=231)$ & t/x 2-value & $p$-value \\
\hline \multicolumn{5}{|l|}{ Sex, n (\%) } \\
\hline Female & $141(60.5)$ & $133(57.6)$ & 0.414 & 0.520 \\
\hline Male & $92(39.5)$ & $98(42.4)$ & & \\
\hline Age & $35.65 \pm 9.77$ & $36.96 \pm 7.82$ & 1.594 & 0.112 \\
\hline \multicolumn{5}{|l|}{ Educational level, n (\%) } \\
\hline$<$ Junior high school & $49(21.0)$ & $42(18.2)$ & & \\
\hline High school & $95(40.8)$ & $80(34.6)$ & 3.836 & 0.147 \\
\hline College and above & 89 (38.2) & $109(47.2)$ & & \\
\hline \multicolumn{5}{|l|}{ Resident location, n (\%) } \\
\hline Urban & $125(53.6)$ & $129(55.8)$ & & \\
\hline Rural & $108(46.4)$ & $102(44.2)$ & 0.266 & 0.635 \\
\hline Total duration of PD, years & $2.49 \pm 1.45$ & & & \\
\hline PDSS baseline & $15.47 \pm 3.82$ & & & \\
\hline PDSS 4-week & $9.51 \pm 3.81$ & & & \\
\hline
\end{tabular}

SLC6A4 rs140701 showed the relative risk of PD for genotype $\mathrm{CC}+\mathrm{CT}$ was lower than for genotype TT $(\mathrm{OR}=0.546 ; 95 \% \mathrm{CI}, 0.371-0.804, p=0.004)$, and after Bonferroni correction for multiple comparisons, the significance remained ( $p=0.028)$.

In addition, the dominant model of rs3813034 showed the relative risk of $\mathrm{PD}$ for genotype $\mathrm{CA}+\mathrm{AA}$ was lower than for genotype $C C(\mathrm{OR}=0.636 ; 95 \% \mathrm{CI}, 0.432-0.935$, $p=0.025$ ). For 5 -HTTLPR polymorphism, the relative risk of PD for genotype LL + LS was lower than for genotype SS $(\mathrm{OR}=0.632 ; 95 \% \mathrm{CI}, 0.436-0.916 ; p=$ $0.021)$. The additive model of rs140701 and rs3813034 showed similar association with $\mathrm{PD}(\mathrm{OR}=0.638,95 \% \mathrm{CI}$ $0.463-0.879, p=0.009 ; \mathrm{OR}=0.721,95 \%$ CI $0.526-0.988$, $p=0.048$; respectively). However, these correlations were no longer significant after adjusting for Bonferroni's multiple testing $(p>0.05)$. Also, there were no significant associations of other SNPs with PD in allelic or other models $(p>0.05)$ (Table 2).

\section{Association between serotonin related gene polymorphisms and early response to sertralines in the treatment of PD}

Finally, we investigated whether variations of gene could predict response to sertraline in Han Chinese population with PD. There was a significant difference in allele and genotype frequency between responders and nonresponders in the 5 -HTTLPR polymorphism $(\mathrm{OR}=0.205$, 95\% CI 0.128-0.328; OR $=0.249$, 95\% CI 0.155-0.401, all $p^{\text {corr }}=0.000$; respectively), and the dominant and recessive model of 5-HTTLPR showed significant association with therapeutic response, indicating the $\mathrm{PD}$ patients with $\mathrm{S}$-allele had a poorer response to sertraline than Lallele carriers. However, genotype and allele frequencies of the other gene polymorphisms were not significantly different between responders and nonresponders $(p>$ 0.05). (Table 3).

\section{Discussion}

In this present study, a significant relationship was found between the SLC6A4 rs140701 polymorphism and PD. The patients with PD possessed significantly higher frequencies of the TT genotype compared to the controls. This result is consistent with the previous study reported that only SNP rs140701 was associated with PD in a 163 sample of African American [9]. Similar studies have found a nominally significant association of rs140701 with social anxiety disorder [38]. The 5-HTT is encoded by the solute carrier family 6 member 4 (SLC6A4) gene, at locus 17q11.2. SNP rs140701 is located in intron 9 of the serotonin transporter gene. SLC6A4 is involved in the transport of serotonin from synaptic spaces to presynaptic neurons, and the pool of available serotonin for subsequent release [39]. Collective evidence suggests the involvement of the serotonin system in the neurobiology and pharmacotherapy of PD [5-7]. Specific SLC6A4 variants may be associated with PD. In addition, previous studies have found 5-HTT knockout mice showed increased anxiety-like behaviour. Such cases have been shown in an animal experiment which found homozygous 5-HTT knockout mice were more anxious [40, 41], while 5-HTT overexpressing mice displayed reduced anxiety-like behaviour [42]. These findings suggest that the importance of the SLC6A4 gene polymorphisms in genetic association studies of PD. However, the SNP rs140701 of function is unclear and remains to be clarified in future studies. 
Table 2 Association of serotonin-related gene polymorphisms with PD risk in Chinese Han population

\begin{tabular}{|c|c|c|c|c|c|c|c|c|}
\hline Gene & SNP & $\begin{array}{l}\text { Alleles and Genotypes } \\
(n, \%)\end{array}$ & $\begin{array}{l}P D \\
(n=233)\end{array}$ & $\begin{array}{l}\text { Controls } \\
(n=231)\end{array}$ & Model & OR $(95 \% \mathrm{Cl})$ & $p$-value & $p$-value ${ }^{\text {corr }}$ \\
\hline \multirow[t]{20}{*}{ SLC6A4 } & \multirow[t]{5}{*}{ rs140701 } & C & $76(16.3)$ & $110(23.8)$ & \multirow[t]{2}{*}{ Allele $^{a}$} & \multirow[t]{2}{*}{$0.624(0.450-0.864)$} & \multirow[t]{2}{*}{0.004} & \multirow[t]{2}{*}{0.028} \\
\hline & & $\mathrm{T}$ & $390(83.7)$ & $352(76.2)$ & & & & \\
\hline & & $\mathrm{CC}$ & $10(4.3)$ & $13(5.6)$ & Additive $^{\mathrm{b}}$ & $0.638(0.463-0.879)$ & 0.009 & 0.063 \\
\hline & & $\mathrm{CT}$ & $56(24.0)$ & $84(36.4)$ & Dominant ${ }^{b}$ & $0.546(0.371-0.804)$ & 0.004 & 0.028 \\
\hline & & $\pi$ & $167(71.7)$ & $134(58.0)$ & Recessive $^{b}$ & $0.752(0.323-1.751)$ & 0.438 & 1 \\
\hline & \multirow[t]{5}{*}{ rs3813034 } & C & $386(82.8)$ & $357(77.3)$ & \multirow[t]{2}{*}{ Allele $^{a}$} & \multirow[t]{2}{*}{$0.705(0.509-0.975)$} & \multirow[t]{2}{*}{0.034} & \multirow[t]{2}{*}{0.238} \\
\hline & & A & $80(17.2)$ & $105(22.7)$ & & & & \\
\hline & & $\mathrm{CC}$ & $164(70.4)$ & $139(60.2)$ & Additive $^{b}$ & $0.721(0.526-0.988)$ & 0.048 & 0.336 \\
\hline & & $C A$ & $58(24.9)$ & 79 (34.2) & Dominant $^{\mathrm{b}}$ & $0.636(0.432-0.935)$ & 0.025 & 0.175 \\
\hline & & AA & $11(4.7)$ & $13(5.6)$ & Recessive $^{b}$ & $0.831(0.364-1.895)$ & 0.662 & 1 \\
\hline & \multirow[t]{5}{*}{ 5-HTTLPR } & L & $107(23.0)$ & $130(28.1)$ & \multirow[t]{2}{*}{ Allele $^{a}$} & \multirow[t]{2}{*}{$0.761(0.566-1.024)$} & \multirow[t]{2}{*}{0.071} & \multirow[t]{2}{*}{0.497} \\
\hline & & $S$ & $359(77.0)$ & $332(71.9)$ & & & & \\
\hline & & $\mathrm{LL}$ & $22(9.4)$ & $20(8.7)$ & Additive $^{\mathrm{b}}$ & $0.785(0.594-1.039)$ & 0.100 & 0.700 \\
\hline & & LS & $63(27.0)$ & $90(39.0)$ & Dominant $^{b}$ & $0.632(0.436-0.916)$ & 0.021 & 0.147 \\
\hline & & SS & $148(63.5)$ & $121(52.3)$ & Recessive $^{\mathrm{b}}$ & $1.100(0.583-2.076)$ & 0.842 & 1 \\
\hline & \multirow[t]{5}{*}{ STin2 } & 10 & $44(9.4)$ & $43(9.3)$ & \multirow[t]{2}{*}{ Allele $^{a}$} & \multirow[t]{2}{*}{$1.016(0.653-1.580)$} & \multirow[t]{2}{*}{0.944} & \multirow[t]{2}{*}{1} \\
\hline & & 12 & $422(90.6)$ & $419(90.7)$ & & & & \\
\hline & & $10 / 10$ & $5(2.1)$ & $2(0.9)$ & Additive $^{\mathrm{b}}$ & $1.015(0.663-1.554)$ & 0.956 & 1 \\
\hline & & $12 / 10$ & $34(14.6)$ & 39 (16.9) & Dominant $^{b}$ & $0.932(0.575-1.508)$ & 0.711 & 1 \\
\hline & & $12 / 12$ & $194(83.3)$ & $190(82.2)$ & Recessive $^{b}$ & $2.511(0.482-13.080)$ & 0.393 & 1 \\
\hline \multirow[t]{5}{*}{ HTRA1 } & \multirow[t]{5}{*}{ rs6295 } & G & $359(77.0)$ & $358(77.5)$ & \multirow[t]{2}{*}{ Allele ${ }^{a}$} & \multirow[t]{2}{*}{$1.026(0.755-1.395)$} & \multirow[t]{2}{*}{0.870} & \multirow[t]{2}{*}{1} \\
\hline & & C & $107(23.0)$ & $104(22.5)$ & & & & \\
\hline & & GG & $138(59.2)$ & $138(59.7)$ & Additive $^{b}$ & $1.026(0.754-1.398)$ & 0.554 & 1 \\
\hline & & GC & 83 (35.6) & $82(35.5)$ & Dominant $^{b}$ & $1.022(0.705-1.480)$ & 0.560 & 1 \\
\hline & & $\mathrm{CC}$ & $12(5.2)$ & $11(4.8)$ & Recessive $^{\mathrm{b}}$ & $1.086(0.469-2.513)$ & 0.772 & 1 \\
\hline HTR2A & rs6313 & G & $163(35.0)$ & $179(38.7)$ & Allele ${ }^{a}$ & $0.868(0.651-1.111)$ & 0.234 & 1 \\
\hline & & $A$ & $303(65.0)$ & $283(61.3)$ & & & & \\
\hline & & $\mathrm{AA}$ & $106(45.5)$ & $86(37.2)$ & Additive $^{\mathrm{b}}$ & $0.859(0.663-1.113)$ & 0.252 & 1 \\
\hline & & GA & $91(39.1)$ & $111(48.1)$ & Dominant ${ }^{b}$ & $0.711(0.490-1.030)$ & 0.061 & 0.427 \\
\hline & & GG & $36(15.4)$ & $34(14.7)$ & Recessive $^{b}$ & $1.059(0.637-1.761)$ & 0.749 & 1 \\
\hline COMT & rs4680 & A & $143(30.7)$ & $118(25.5)$ & Allele ${ }^{a}$ & $1.291(0.969-1.720)$ & 0.081 & 0.567 \\
\hline & & G & $323(69.3)$ & $344(74.5)$ & & & & \\
\hline & & AA & $24(10.3)$ & $15(6.5)$ & Additive $^{\mathrm{b}}$ & $1.284(0.65-1.707)$ & 0.118 & 0.826 \\
\hline & & GA & $95(40.8)$ & $88(38.1)$ & Dominant $^{b}$ & $1.297(0.901-1.869)$ & 0.175 & 1 \\
\hline & & GG & $114(48.9)$ & $128(55.4)$ & Recessive $^{b}$ & $1.654(0.844-3.240)$ & 0.236 & 1 \\
\hline
\end{tabular}

"A" represent wild type and "a" represent mutant type: allele, a vs. $A$; additive, aa vs. Aa vs. AA; dominant, aa + Aa vs. AA, recessive, aa vs. Aa +AA. ${ }^{a}$ Chi-square test, ${ }^{b}$ Logistic regression analyses by adjustment for age, gender, educational level and resident location. $P^{\text {corr. }}$ : adjusted by boferroni multiple comparison correction

However, we did not find any significant association evidence within the 5-HTTLPR, rs3813034 and STin2 polymorphisms of the SLC6A4 gene, which is consistent with findings from other studies and meta-analysis demonstrating that the 5-HTTLPR and STin2 were not associated with PD [43, 44]. However, inconsistent with previous research which has found the rs3813034 of
SLC6A4 is a putative risk factor for PD and other behavioral disorders that involve dysregulation of serotonergic neurotransmission [45]. Additionally, we found no significant statistical differences in the genotype distributions or allele frequencies of the SNPs (5-HTR1A rs6295, 5-HTR2A rs6313 and COMT rs4680) between PD and control groups. In a study comprised of 119 PD 
Table 3 Genotype and allele frequencies of serotonin-related gene polymorphisms between responder and nonresponder

\begin{tabular}{|c|c|c|c|c|c|c|c|c|}
\hline Gene & SNP & $\begin{array}{l}\text { Alleles and Genotypes } \\
(n, \%)\end{array}$ & $\begin{array}{l}\text { Responder } \\
(n=98)\end{array}$ & $\begin{array}{l}\text { Nonresponder } \\
(n=135)\end{array}$ & Model & OR $(95 \% \mathrm{Cl})$ & $p$-value & $p$-value ${ }^{\text {corr }}$ \\
\hline \multirow[t]{20}{*}{ SLC6A4 } & \multirow[t]{5}{*}{ rs140701 } & C & 37 (18.9) & 39 (14.4) & \multirow[t]{2}{*}{ Allele $^{a}$} & \multirow[t]{2}{*}{$0.726(0.443-1.188)$} & \multirow[t]{2}{*}{0.201} & \multirow[t]{2}{*}{1} \\
\hline & & $\mathrm{T}$ & $159(81.1)$ & $231(85.6)$ & & & & \\
\hline & & $\mathrm{CC}$ & $5(5.1)$ & $5(3.7)$ & Additive $^{\mathrm{b}}$ & $0.638(0.470-1.198)$ & 0.159 & 1 \\
\hline & & CT & $27(27.6)$ & $29(21.5)$ & Dominant ${ }^{\mathrm{b}}$ & $0.694(0.391-1.232)$ & 0.160 & 1 \\
\hline & & $\pi$ & $66(67.3)$ & $101(74.8)$ & Recessive $^{b}$ & $0.715(0.201-2.542)$ & 0.446 & 1 \\
\hline & \multirow[t]{5}{*}{ rs3813034 } & C & $155(79.1)$ & 231 (85.6) & \multirow[t]{2}{*}{ Allele $^{a}$} & \multirow[t]{2}{*}{$0.638(0.394-1.035)$} & \multirow[t]{2}{*}{0.067} & \multirow[t]{2}{*}{0.469} \\
\hline & & A & $41(20.9)$ & $39(14.4)$ & & & & \\
\hline & & $\mathrm{CC}$ & $63(64.3)$ & $101(74.8)$ & Additive $^{b}$ & $0.669(0.423-1.060)$ & 0.113 & 0.791 \\
\hline & & CA & 29 (29.6) & $29(21.5)$ & Dominant ${ }^{b}$ & $0.606(0.344-1.069)$ & 0.128 & 0.896 \\
\hline & & AA & $6(6.1)$ & $5(3.7)$ & Recessive $^{b}$ & $0.590(0.175-1.991)$ & 0.332 & 1 \\
\hline & \multirow[t]{5}{*}{ 5-HTTLPR } & L & 76 (38.8) & $31(11.5)$ & \multirow[t]{2}{*}{ Allele $^{a}$} & \multirow[t]{2}{*}{$0.205(0.128-0.328)$} & \multirow[t]{2}{*}{0.000} & \multirow[t]{2}{*}{0.000} \\
\hline & & S & $120(61.2)$ & $239(88.5)$ & & & & \\
\hline & & LL & $16(16.3)$ & $6(4.4)$ & Additive $^{b}$ & $0.249(0.155-0.401)$ & 0.000 & 0.000 \\
\hline & & LS & $44(44.9)$ & $19(14.1)$ & Dominant ${ }^{b}$ & $0.144(0.079-0.261)$ & 0.000 & 0.000 \\
\hline & & SS & $38(38.8)$ & $110(81.5)$ & Recessive $^{\mathrm{b}}$ & $0.238(0.090-0.634)$ & 0.004 & 0.029 \\
\hline & \multirow[t]{5}{*}{ STin2 } & 10 & $22(11.2)$ & $22(8.1)$ & \multirow[t]{2}{*}{ Allele $^{a}$} & \multirow[t]{2}{*}{$0.702(0.377-1.307$} & \multirow[t]{2}{*}{0.262} & \multirow[t]{2}{*}{1} \\
\hline & & 12 & $174(88.8)$ & $248(91.9)$ & & & & \\
\hline & & $10 / 10$ & $3(3.1)$ & $2(1.5)$ & Additive $^{\mathrm{b}}$ & $0.734(0.410-1.315)$ & 0.372 & 1 \\
\hline & & $12 / 10$ & $16(16.3)$ & $18(13.3)$ & Dominant $^{\mathrm{b}}$ & $0.723(0.363-1.442)$ & 0.454 & 1 \\
\hline & & $12 / 12$ & 79 (80.6) & $115(85.2)$ & Recessive $^{b}$ & $0.476(0.078-2.905)$ & 0.428 & 1 \\
\hline \multirow[t]{5}{*}{ HTRA1 } & \multirow[t]{5}{*}{ rs6295 } & G & $151(77.0)$ & $208(77.0)$ & \multirow[t]{2}{*}{ Allele ${ }^{a}$} & \multirow[t]{2}{*}{$1.000(0.646-1.549)$} & \multirow[t]{2}{*}{0.999} & \multirow[t]{2}{*}{1} \\
\hline & & C & $45(23.0)$ & $62(23.0)$ & & & & \\
\hline & & GG & $59(60.2)$ & $79(58.5)$ & Additive $^{\mathrm{b}}$ & $1.000(0.645-1.551)$ & 0.985 & 1 \\
\hline & & GC & $33(33.7)$ & $50(37.0)$ & Dominant ${ }^{\mathrm{b}}$ & $1.072(0.631-1.822)$ & 0.903 & 1 \\
\hline & & CC & $6(6.1)$ & $6(4.4)$ & Recessive $^{b}$ & $0.713(0.223-2.281)$ & 0.826 & 1 \\
\hline HTR2A & rs6313 & G & $62(31.6)$ & $101(37.4)$ & Allele $^{a}$ & $1.292(0.875-1.906)$ & 0.197 & 1 \\
\hline & & $A$ & $134(68.4)$ & $169(62.6)$ & & & & \\
\hline & & AA & $48(49.0)$ & $58(43.0)$ & Additive $^{\mathrm{b}}$ & $1.252(0.869-1.805)$ & 0.199 & 1 \\
\hline & & GA & $38(38.8)$ & $53(39.3)$ & Dominant $^{b}$ & $1.274(0.756-2.149)$ & 0.233 & 1 \\
\hline & & GG & $12(12.2)$ & $24(17.8)$ & Recessive $^{b}$ & $1.550(0.733-3.274)$ & 0.355 & 1 \\
\hline COMT & rs4680 & $A$ & $66(33.7)$ & $77(28.5)$ & Allele $^{a}$ & $0.786(0.528-1.169)$ & 0.234 & 1 \\
\hline & & G & $130(66.3)$ & $193(71.5)$ & & & & \\
\hline & & $\mathrm{AA}$ & $11(11.2)$ & $13(9.6)$ & Additive $^{\mathrm{b}}$ & $0.793(0.537-1.172)$ & 0.294 & 1 \\
\hline & & GA & $44(44.9)$ & $51(37.8)$ & Dominant ${ }^{b}$ & $0.705(0.418-1.189)$ & 0.174 & 1 \\
\hline & & GG & $43(43.9)$ & $71(52.6)$ & Recessive $^{b}$ & $0.843(0.361-1.969)$ & 0.954 & 1 \\
\hline
\end{tabular}

"A" represent wild type and "a" represent mutant type: allele, a vs. $A$; additive, aa vs. Aa vs. $A A$; dominant, aa + Aa vs. $A A$, recessive, aa vs. Aa +AA. ${ }^{a}$ Chi-square test, ${ }^{b}$ Logistic regression analyses by adjustment for age, gender, educational level and resident location. $P^{\text {corr. }}$ : adjusted by boferroni multiple comparison correction

patients and 119 healthy controls from Japanese population, no significant differences were found in the allele frequencies or genotype distributions of the COMT rs4680 or the 5-HT1A (rs6295) between PD patients and controls [10], but other studies have found significant relationship between the COMT Val158Met (rs4680) polymorphism and PD [14, 15]. In a meta analysis, the
COMT Val158Met polymorphism has been found to be associated with PD in European ancestry, but not Asian ancestry [46]. Previous studies also found pure PD was associated with HTR2A $102 \mathrm{~T}-\mathrm{C}$ (rs6313) polymorphism [47], but not in other study [14]. The above findings of genetic association studies are limited and inconsistent. These mixed results of studies might be attributable to 
different samples, sex, races, agoraphobia co-morbidity or severity of PD. For example, previous study showed that the HTR2A rs6311 polymorphism was associated with the severity of PD [43]. Above all, these conflicting findings indicate that the contribution of genetic factors to PD may involve a complex network of variants.

In the present study, we only found significant correlation between 5-HTTLPR polymorphism and treatment response to sertraline after 4-weeks treatment for PD. The results of our study indicated the PD patients with $\mathrm{S}$-allele was linked to poorer response to sertraline during the early stage of treatment, suggesting that 5 -HTTL PR could be a predictor of response to sertraline treatment. 5-HTTLPR is a 44 base pair insertion-deletion polymorphism which can exist as a long (L) variant of a 16 repeat sequence or a short (S) variant of 14 repeats [48]. Previous researches indicated the L allele was associated with higher levels of transcription and concentrations of 5-HTT mRNA compared to the $\mathrm{S}$ allele, and the short (S) allele of the 5-HTTLPR polymorphism resulted in less efficient transcription [49-51]. This may explain the fact to some extent that the SSRIs are effective in the treatment of PD with the SLC6A4 being the primary drug target. These findings may contribute to our understanding of the association between 5-HTTLPR polymorphism and antidepressant response. Consistent study found the 5-HTTLPR low-expression genotypes showed a more favorable response to exposure-based behavior therapy in PD with agoraphobia [52]. Similar findings were found in subjects with depressive disorder treated with sertraline [53]. However, previous report found no association of the 5-HTTLPR polymorphism with treatment response in a sample size of $102 \mathrm{PD}$ patients treated with sertraline or paroxetine [54]. Also, there was no significant associations between the 5-HTTLPR polymorphism and sertraline responses in MDD patients [55]. On the one hand, other polymorphisms of SLC6A4 may have a combined effect with 5HTTLPR. In addtion, the variants of cytochrome P450 enzyme genes may also contribute to the pharmacokinetics. One study found the CYP2C19 genetic polymorphism is associated with Escitalopram treatment response in Chinese patients with PD [56]. On the other hand, functional variants in SLC6A4 may be related to epigenetic mechanisms and affect gene expression. For instance, epigenetic modifications of SLC6A4 gene is showing promising results as biomarkers for prediction of antidepressant response [57]. Notably, evidence has been shown that different ethnicities responded differently to antidepressants possibly due to the variants in the SLC6A4 gene. One Meta-analysis showed 5-HTTL PR may be a predictor of antidepressant response and remission in Caucasians, while it does not appear to play a major role in Asians [58]. Last but not the least, we did not find the relationship between other gene polymorphisms and treatment response to sertraline. This is inconsistent with previous studies that found the 5HT1A receptor $-1019 \mathrm{C} / \mathrm{G}$ polymorphism was strongly associated with response to treatment in PD receiving sertraline or paroxetinethe $[54,59]$. Another study suggested that the genetic variant of the COMT enzyme may be related to treatment response to paroxetine in PD [60]. Inconsistent results may be related to small sample size, short follow-up periods, definition of response, antidepressant choice and ethnic differences. In addition, gene-environment interactions may also contribute to these inconsistent findings and provide more robust predictors of treatment response.

\section{Conclusions}

The present study suggests that the SLC6A4 rs140701 variant may be associated with susceptibility to $\mathrm{PD}$, and 5HTTLPR polymorphism may be a predictor of response to sertralines in the treatment of PD. However, the results of our study should be considered preliminary in light of several limitations: (1) The sample size was limited and only from Sichuan provinces of western China, which may not completely represent the Chinese ethnicity. (2) The etiology of PD is complex and comprises environmental and genetic factors, a potential gene-environment interaction or epigenetics study should be investigated. (3) We did not measure the relationship between plasma sertraline concentration and clinical response.

\section{Supplementary information}

Supplementary information accompanies this paper at https://doi.org/10. 1186/s12888-020-02790-y.

Additional file 1: Table S1. Characteristics of circadian genes and SNPS in this study

Additional file 2: Table S2. The primer sequence in PCR mixture Additional file 3: Table S3. the probe sequence in probe mixture Additional file 4: Table S4. Power of the study at current sample size Additional file 5: Figure S1. PD patients recruit flow chart.

\section{Abbreviations \\ COMT: Catechol-O-Methyltransferase; Cls: Confidence Intervals; CYP450: Cytochrome P450; DSM-IV: Diagnostic and Statistical Manual of Mental Disorders fourth edition; HWE: Hardy-Weinberg Equilibrium; L: Long: LD: linkage disequilibrium; MDD: Major Depressive Disorder; ORs: Odds Ratios; PD: Panic disorder; PDSS: Panic Disorder Severity Scale; PCR: Polymerase Chain Reaction; SCID: Structured Clinical Interview for DSM- IV; SNPs: Single Nucleotide Polymorphism; S: Short; SLC6A4: Solute Carrier Family 6 Member 4; SSRIs: Selective Serotonin-Reuptake Inhibitors; STin2: intron 2; 5-HTR1A: 1A receptor; 5-HTR2A: 5-Hydroxytryptamine 2A receptor; 5-HTT: Serotonin Transporter; 5-HTTLPR: Serotonin-Transporter- Linked Polymorphic Region}

\section{Acknowledgements}

The authors would like to thank all participants in this study. we thank Shanghai Genesky Bio-Tech Co., Ltd. for their excellent technical assistance with the genotyping analyses. 


\section{Authors' contributions}

ZLZ was critically involved in the study design and wrote the manuscript. YLH, JYW and WJM were involved in subject recruitment. BZ guided this research and supervised the entire project. All authors read and approved the final manuscript

\section{Funding}

This study was supported by grants from National Natural Science Foundation of China(81801360). In addition, this study was also supported by grants from the Chinese academy of medical sciences (2019PT310020). The funding bodies played no role in the design of the study and collection, analysis, and interpretation of data and in writing the manuscript.

\section{Availability of data and materials}

The datasets used and analyzed during the current study are available from the corresponding author on reasonable request.

\section{Ethics approval and consent to participate}

The study was approved by the Sichuan Provincial People's Hospital ethics committee, reference number: (2016) Ethics Review (29). All individuals provided written informed consent prior to the initiation of study procedures.

\section{Consent for publication}

Not applicable.

\section{Competing interests}

The authors declare that they have no competing interests.

Received: 27 February 2020 Accepted: 20 July 2020

Published online: 28 July 2020

\section{References}

1. Kessler RC, Stang PE, Wittchen HU, Ustun TB, Roy-Burne PP, Walters EE. Lifetime panic-depression comorbidity in the National Comorbidity Survey. Arch Gen Psychiatry. 1998;55:801-8.

2. Kessler RC, Chiu WT, Jin R, Ruscio AM, Shear K, Walters EE. The epidemiology of panic attacks, panic disorder, and agoraphobia in the National Comorbidity Survey Replication. Arch Gen Psychiatry. 2006;63:415-24.

3. Schumacher J, Kristensen AS, Wendland JR, Nöthen MM, Mors O, FJ MM. The genetics of panic disorder. J Med Genet. 2011;48:361-8.

4. Hettema JM, Neale MC, Kendler KS. A review and meta-analysis of the genetic epidemiology of anxiety disorders. Am J Psychiatry. 2001;158:1568-78.

5. Maron E, Shlik J. Serotonin function in panic disorder: important, but why? Neuropsychopharmacology. 2006;31:1-11.

6. Graeff FG. Translational approach to the pathophysiology of panic disorder: focus on serotonin and endogenous opioids. Neurosci Biobehav Rev. 2017; 76:48-55.

7. Mochcovitch MD, Nardi AE. Selective serotonin-reuptake inhibitors in the treatment of panic disorder: a systematic review of placebo-controlled studies. Expert Rev Neurother. 2010;10:1285-93.

8. Maron E, Lang A, Tasa G, Liivlaid L, Töru I, Must A, et al. Associations between serotonin-related gene polymorphisms and panic disorder. Int J Neuropsychopharmacol. 2005;8:261-6.

9. Strug LJ, Suresh R, Fyer AJ, Talati A, Adams PB, Li W, et al. Panic disorder is associated with the serotonin transporter gene (SLC6A4) but not the promoter region (5-HTTLPR). Mol Psychiatry. 2010;15:166-76.

10. Watanabe $T$, Ishiguro $S$, Aoki A, Ueda M, Hayashi Y, Akiyama K, et al. Genetic polymorphism of 1019C/G (rs6295) promoter of serotonin 1A receptor and catechol-O-methyltransferase in panic disorder. Psychiatry Investig. 2017;14:86-92.

11. Choi WS, Lee BH, Yang JC, Kim YK. Association study between 5-HT1A receptor gene $C(-1019) \mathrm{G}$ polymorphism and panic disorder in a Korean population. Psychiatry Investig. 2010;7:141-6.

12. Yoon HK, Yang JC, Lee HJ, Kim YK. The association between serotoninrelated gene polymorphisms and panic disorder. J Anxiety Disord. 2008;22: 1529-34.

13. Rothe C, Koszycki D, Bradwejn J, King N, De Luca V, Shaikh S, et al. Association study of serotonin-2A receptor gene polymorphism and panic disorder in patients from Canada and Germany. Neurosci Lett. 2004;363:276-9.
14. Karacetin G, Bayoglu B, Cengiz M, Demira T, Kocabasoglu N, Uysal O, et al. Serotonin-2A receptor and catechol-O-methyltransferase polymorphisms in panic disorder. Prog Neuro-Psychopharmacol Biol Psychiatry. 2012;36:5-10.

15. Rothe C, Koszycki D, Bradwejn J, King N, De Luca, V, Tharmalingam S, et al. Association of the Val158Met catechol O-methyltransferase genetic polymorphism with panic disorder. Neuropsychopharmacology. 2006; 31:2237-2242.

16. Annerbrink K, Westberg L, Olsson M, Olsson M, Allgulander S, Andersch S, et al. Association between the catechol-O-methyltransferase Val158Met polymorphism and panic disorder: a replication. Psychiatry Res. 2010;178:196-8.

17. Kim H, Lim SW, Kim S, Kim JW, Chang YH, Carroll BJ, et al. Monoamine transporter gene polymorphisms and antidepressant response in koreans with late-life depression. JAMA. 2006;296:1609-18.

18. Dong ZQ, Li XR, He L, He G, Yu T, Sun XL. 5-HTR1A and 5-HTR2A genetic polymorphisms and SSRI antidepressant response in depressive Chinese patients. Neuropsychiatr Dis Treat. 2016;12:1623-9.

19. Myung W, Lim SW, Kim S, Kim H, Chung JW, Seo MY, et al. Serotonin transporter genotype and function in relation to antidepressant response in Koreans. Psychopharmacology. 2013;225:283-90.

20. Corregiari FM, Bernik M, Cordeiro Q, Vallada H. Endophenotypes and serotonergic polymorphisms associated with treatment response in obsessive-compulsive disorder. Clinics (Sao Paulo). 2012;67:335-40.

21. Kato M, Fukuda T, Wakeno M, Okugawa G, Takekita Y, Watanabe S, et al. Effect of 5-HT1A gene polymorphisms on antidepressant response in major depressive disorder. Am J Med Genet B Neuropsychiatr Genet. 2009;150B:115-23.

22. Gudayol-Ferré E, Herrera-Guzmán I, Camarena B, Cortés-Penagos C, HerreraAbarca JE, Martínez-Medina P, et al. The role of clinical variables, neuropsychological performance and SLC6A4 and COMT gene polymorphisms on the prediction of early response to fluoxetine in major depressive disorder. J Affect Disord. 2010;127:343-51.

23. Basu A, Chadda RK, Sood M, Kaur H, Kukreti R. Association of serotonin transporter (SLC6A4) and receptor (5HTR1A, 5HTR2A) polymorphisms with response to treatment with escitalopram in patients with major depressive disorder: a preliminary study. Indian J Med Res. 2015;142:40-5.

24. Niitsu T, Fabbri C, Bentini F, Serretti A. Pharmacogenetics in major depression: a comprehensive meta-analysis. Prog Neuro-Psychopharmacol Biol Psychiatry. 2013;45:183-94.

25. Arias B, Serretti A, Lorenzi C, Gastó C, Catalán R, Fañanás L. Analysis of COMT gene (Val 158 met polymorphism) in the clinical response to SSRIs in depressive patients of European origin. J Affect Disord. 2006;90:251-6.

26. Gudayol-Ferré E, Herrera-Guzmán I, Camarena B, Cortés-Penagos C, HerreraAbarca JE, Martínez-Medina P, et al. Prediction of remission of depression with clinical variables, neuropsychological performance, and serotonergic/ dopaminergic gene polymorphisms. Hum Psychopharmacol. 2012;27:577-86.

27. Nonen S, Kato M, Takekita Y, Wakeno M, Sakai S, Serretti A, et al. Polymorphism of rs3813034 in serotonin transporter gene SLC6A4 is associated with the selective serotonin and serotonin-norepinephrine reuptake inhibitor response in depressive disorder: sequencing analysis of SLC6A4. J Clin Psychopharmacol. 2016;36:27-31.

28. Andre K, Kampman O, Illi A, Viikki M, Setälä-Soikkeli E, Mononen N, et al. SERT and NET polymorphisms, temperament and antidepressant response. Nord J Psychiatry. 2015;69:531-8.

29. Yeh YW, Chen CJ, Jang FL, Kuo SC, Chen CY, Liang CS, et al. SLC6A2 variants may predict remission from major depression after venlafaxine treatment in Han Chinese population. J Psychiatr Res. 2015;61:33-9.

30. Camarena B, Álvarez-Icaza D, Hernández S, Aguilar A, Münch L, Martínez C, et al. Association study between serotonin transporter gene and Fluoxetine response in Mexican patients with major depressive disorder. Clin Neuropharmacol. 2019;42:9-13.

31. Denys D, Van Nieuwerburgh F, Deforce D, Westenberg HG. Prediction of response to paroxetine and venlafaxine by serotonin-related genes in obsessive-compulsive disorder in a randomized, double-blind trial. J Clin Psychiatry. 2007;68:747-53.

32. Szegedi A, Rujescu D, Tadic A, Müller MJ, Kohnen R, Stassen HH, et al. The catechol-O-methyltransferase Val108/158Met polymorphism affects shortterm treatment response to mirtazapine, but not to paroxetine in major depression. Pharmacogenomics J. 2005;5:49-53.

33. Kamijima K, Kuboki T, Kumano H, Burt T, Cohen G, Arano I, et al. A placebocontrolled, randomized withdrawal study of sertraline for panic disorder in Japan. Int Clin Psychopharmacol. 2005;20:265-73.

34. First MB, Spitzer RL, Gibbon M, Williams JBW. Structured clinical interview for DSM-IV Axis I disorders (SCID-I) (clinical version). Washington DC: American Psy-chiatric Press Inc; 1997. 
35. Shear MK, Brown TA, Barlow DH, Money R, Sholomskas DE, Woods SW, et al. Multicenter collaborative panic disorder severity scale. Am J Psychiatry. 1997;154:1571-5.

36. Xiong HF, Li ZJ, Han HY, Xu ZY, Guo ZH, Yao SM, et al. Panic disorder severity scale-chinese version: reliability and validity. Chin J Psychiatry. 2012; 45:285-8.

37. Furukawa TA, Katherine Shear M, Barlow DH, Gorman JM, Woods SW, Money $\mathrm{R}$, et al. Evidence-based guidelines for interpretation of the panic disorder severity scale. Depress Anxiety. 2009;26:922-9.

38. Forstner AJ, Rambau S, Friedrich N, Ludwig KU, Böhmer AC, Mangold E, et al. Further evidence for genetic variation at the serotonin transporter gene SLC6A4 contributing toward anxiety. Psychiatr Genet. 2017;27:96-102.

39. Lesch KP, Gutknecht L. Pharmacogenetics of the serotonin transporter. Prog Neuro-Psychopharmacol Biol Psychiatry. 2005;29:1062-73.

40. Bodden C, Richter SH, Schreiber RS, Kloke V, Gerß J, Palme R, et al. Benefits of adversity?! How life history affects the behavioral profile of mice varying in serotonin transporter genotype. Front Behav Neurosci. 2015;9:47.

41. Meyer N, Richter SH, Schreiber RS, Kloke V, Kaiser S, Lesch KP, et al. The unexpected effects of beneficial and adverse social experiences during adolescence on anxiety and aggression and their modulation by genotype. Front Behav Neurosci. 2016;10:97

42. Line SJ, Barkus C, Coyle C, Jennings KA, Deacon RM, Lesch KP, et al. Opposing alterations in anxiety and species-typical behaviours in serotonin transporter overexpressor and knockout mice. Eur Neuropsychopharmacol. 2011;21:108-16.

43. Saiz PA, Martínez-Barrondo S, García-Portilla MP, Corcoran P, Morales B, Bascaran MT, et al. Role of serotonergic polymorphisms in the clinical severity of the panic disorder. Rev Psiquiatr Salud Ment. 2009;2:35-41.

44. Blaya C, Salum GA, Lima MS, Leistner-Segal S, Manfro GG. Lack of association between the serotonin transporter promoter polymorphism (5HTTLPR) and panic disorder: a systematic review and meta-analysis. Behav Brain Funct. 2007;3:41.

45. Gyawali S, Subaran R, Weissman MM, Hershkowitz D, McKenna MC, Talati A, et al. Association of a polyadenylation polymorphism in the serotonin transporter and panic disorder. Biol Psychiatry. 2010;67:331-8.

46. Howe AS, Buttenschøn HN, Bani-Fatemi A, Maron E, Otowa T, Erhardt A, et al. Candidate genes in panic disorder: meta-analyses of $23 \mathrm{common}$ variants in major anxiogenic pathways. Mol Psychiatry. 2016;21:665-79.

47. Maron E, Nikopensius T, Kõks S, Altmäe S, Heinaste E, Vabrit K, et al. Association study of 90 candidategene polymorphisms in panic disorder. Psychiatr Genet. 2005;15:17-24.

48. Heils A, Teufel A, Petri S, Stöber G, Riederer P, Bengel D, et al. Allelic variation of human serotonin transporter gene expression. J Neurochem. 1996:66:2621-4.

49. Lesch KP, Bengel D, Heils A, Sabol SZ, Greenberg BD, Petri S, et al. Association of anxiety-related traits with a polymorphism in the serotonin transporter gene regulatory region. Science. 1996;274:1527-31.

50. Hariri AR, Mattay VS, Tessitore A, Kolachana B, Fera F, Goldman D, et al. Serotonin transporter genetic variation and the response of the human amygdala. Science. 2002;297:400-3.

51. Hu XZ, Lipsky RH, Zhu G, Akhtar LA, Taubman J, Greenberg BD, et al. Serotonin transporter promoter gain-of-function genotypes are linked to obsessive-compulsive disorder. Am J Hum Genet. 2006;78:815-26.

52. Knuts I, Esquivel G, Kenis G, Overbeek T, Leibold N, Goossens L, et al. Therapygenetics: 5-HTTLPR genotype predicts the response to exposure therapy for agoraphobia. Eur Neuropsychopharmacol. 2014;24:1222-8.

53. Umene-Nakano W, Yoshimura R, Ueda N, Suzuki A, Ikenouchi-Sugita A, Hori $\mathrm{H}$, et al. Predictive factors for responding to sertraline treatment: views from plasma catecholamine metabolites and serotonin transporter polymorphism. J Psychopharmacol. 2010;24:1764-71.

54. Yevtushenko OO, Oros MM, Reynolds GP. Early response to selective serotonin reuptake inhibitors in panic disorder is associated with a functional 5-HT1A receptor gene polymorphism. J Affect Disord. 2010;123:308-11.

55. Dogan O, Yuksel N, Ergun MA, Yilmaz A, Ilhan MN, Karslioglu HE, et al. Serotonin transporter gene polymorphisms and sertraline response in major depression patients. Genet Test. 2008;12:225-31.

56. He Q, Yuan Z, Liu Y, Zhang J, Yan H, Shen L, et al. Correlation between cytochrome P450 2C19 genetic polymorphism and treatment response to escitalopram in panic disorder. Pharmacogenet Genomics. 2017:27:279-84.

57. Lisoway AJ, Zai CC, Tiwari AK, Kennedy JL. DNA methylation and clinical response to antidepressant medication in major depressive disorder: a review and recommendations. Neurosci Lett. 2018;669:14-23.
58. Porcelli S, Fabbri C, Serretti A. Meta-analysis of serotonin transporter gene promoter polymorphism (5-HTTLPR) association with antidepressant efficacy. Eur Neuropsychopharmacol. 2012;22:239-58.

59. Ishiguro S, Watanabe T, Ueda M, Saeki Y, Hayashi Y, Akiyama K, et al. Determinants of pharmacodynamic trajectory of the therapeutic response to paroxetine in Japanese patients with panic disorder. Eur J Clin Pharmacol. 2011;67:1213-21.

60. Woo JM, Yoon KS, Choi YH, Oh KS, Lee YS, Yu BH. The association between panic disorder and the L/L genotype of catechol-O-methyltransferase. J Psychiatr Res. 2004;38:365-70.

\section{Publisher's Note}

Springer Nature remains neutral with regard to jurisdictional claims in published maps and institutional affiliations.

\section{Ready to submit your research? Choose BMC and benefit from:}

- fast, convenient online submission

- thorough peer review by experienced researchers in your field

- rapid publication on acceptance

- support for research data, including large and complex data types

- gold Open Access which fosters wider collaboration and increased citations

- maximum visibility for your research: over $100 \mathrm{M}$ website views per year

At BMC, research is always in progress.

Learn more biomedcentral.com/submissions 